\title{
Gridlocked in the city: kinship and witchcraft among Wayao street vendors in Dar es Salaam, Tanzania
}

\author{
Alexis Malefakis
}

\begin{abstract}
Introduction
For a group of Wayao street vendors in the city of Dar es Salaam, Tanzania, kinship relations were simultaneously an advantage and a hindrance. Relatives had helped them migrate to the city from their home village in the south of the country and had housed them for the first few months. Once in the city, each had been introduced to the business of selling second-hand women's shoes on the streets by one of his relatives. As they had worked together closely for many years by the time of my research in the early $2010 \mathrm{~s},{ }^{1}$ there was a degree of mutual dependence among the vendors that gave them access to continuously updated market knowledge, allowed them to share materials and tools to refurbish their merchandise, and offered them a safety net that provided a modicum of support in times of need. Nonetheless, while cooperation was indispensable in their demanding line of business, they shared a mutual contempt and mistrust that made substantial collaboration impossible.

Over the years, the group had grown to more than forty young men who shared a backyard in the inner city as their kijiweni or meeting point. This was their workspace, where they prepared the second-hand shoes they obtained from the market before reselling them on the streets. Almost all of the shoe vendors working at the kijiweni were Wayao who had grown up as relatives and neighbours in a village in one of the poorest regions of the country. They had all attended the same village school and followed one another's path to the city. But, despite the group's close and multiplex relations and the intimate mutual knowledge this engendered, many of them complained that respect and trust were lacking from their daily interactions. In fact, when I asked some of the vendors about the composition of their 'group', they denied that any such 'group' even existed. Instead, they described a situation in which they felt that they all fended for themselves and did not expect any significant help from their relatives or fellow Wayao at the kijiweni. Individually struggling to improve their own economic and social circumstances, yet unable to disentangle themselves from their intimate kinship relations, they experienced their situation at the kijiweni as a kind of social gridlock.
\end{abstract}

\footnotetext{
Alexis Malefakis is a researcher and curator at the Ethnographic Museum at the University of Zurich. His research focuses on urban anthropology, the anthropology of work, material culture, praxeology and skills. He has published on street vending in Tanzania, the trade in African art in Europe, and skills in wire model building in Burundi. Email: malefakis@vmz. uzh.ch

${ }^{1}$ This article is based on fifteen months of ethnographic fieldwork conducted between 2010 and 2013 with a group of male street vendors who specialized in trading second-hand women's shoes in the central business district of Dar es Salaam.
}

(C) International African Institute 2018 
The Wayao regarded the antisocial sentiments with which their relationships were burdened as a 'heritage' that they had brought with them from the village where they grew up. But, despite its assumed origin in their rural homes, the notion of kinship as confinement took shape and became efficacious against the backdrop of the Wayao's lived urban experience. As I show in this article, they perceived the city as a heterogeneous social environment that could offer them potential opportunities to associate with people from other ethnic and social backgrounds, and thus to broaden their horizons in terms of both their business opportunities and their outlook on life more generally - this was the lure of the city that had attracted them there in the first place. In other words, the Wayao hoped to participate in that urban heterogeneity that AbdouMaliq Simone described as an 'intersection of socialities' that complement each other to form 'an infrastructure for innovative economic transactions in the inner city' (Simone 2004: 407, 419). For reasons I will detail, however, the Wayao at the kijiweni conceived of their sociality as an island only peripherally connected to that peopled infrastructure of the city. According to their own understanding, their rural upbringing had left such an indelible psychological imprint on them that they lacked the 'readiness to switch gears', to change focus and location and to experiment, which Simone asserted was characteristic of urban residents in Africa (ibid.: 424). It is important to note, however, that this self-ascribed inability to cope with urban life did not render the group of Wayao I describe here as misplaced villagers or ill-adjusted 'tribesmen' in town (cf. Mayer 1963). Indeed, most of them had moved to the city as teenagers and had spent the better part of their adult lives there. As veterans of itinerant trading, they knew the city extremely well and skilfully navigated the rapidly changing social environment of the streets. Instead of being regarded as evidence of their insufficient integration into the city, their negative self-image should in fact be understood as a narrative strategy they employed to make sense of their perceived inability to realize their dream of a better life there. Their narrative of kinship, in other words, was moulded through their engagement with the city.

Paradoxically, disintegrative sentiments of suspicion and contempt did not contradict the shoe vendors' intimacy and dependency, but were a corollary of them. Because of their shared past in the village, their intimate kinship relations and their all-encompassing mutual knowledge, they felt unable to trust one another. Instead of providing a basis for reciprocal trust (cf. Corsin Jiménez 2011: 178, 181), the transparency they attributed to their social relations had flipped into mutual disrespect, vilification and mistrust. The social proximity and intimacy of their relations were experienced as a hindrance to their individual aspirations for success. This claustrophobic sentiment was further aggravated by the city's dense social environment - and particularly by the physical confinement of the kijiweni, which enabled mutual surveillance and created a feeling of suspicion. The shoe vendors' negative associations with their close social relations were expressed most dramatically as accusations of uchawi (Swahili: witchcraft). ${ }^{2}$ Some

\footnotetext{
${ }^{2}$ For a discussion of the problem of defining the term 'witchcraft', with all its connotations of various phenomena and concepts in Africa and elsewhere, see Moore and Sanders (2006: 3-6). In order to avoid subsuming the ideas and phenomena I describe here under the English term 'witchcraft', which refers to a European historical experience and not to contemporary African realities,
} 
of them blamed their colleagues for their own inability to succeed in business, and they expressed their frustration through the idiom of uchawi. In that sense, uchawi accusations comprised a negative 'syndrome of belonging' (Geschiere 2003: 44) that was not intended to sever social relations but provided an outlet to express the anxieties that came with a stifling mutual dependence. The notion of uchawi, surprisingly, even generated an integrative momentum among the shoe vendors, since it was grounded in a notion of sameness that was associated with kinship relations. As I show in this article, when the vendors blamed one of their colleagues who was not related to them through kinship of using uchawi in order to achieve individual success and thereby to outdo them, they reinforced their claim to sameness by calling him to order, thus replicating kinship-like relations with him.

\section{The micro-politics of sociality at the kijiweni}

Anthropological research on witchcraft, magic and sorcery in African contexts has produced a vast corpus of literature dealing with such diverse theoretical matters as the cultural construction of rationality (Evans-Pritchard 1965; 1978; Heinz 1997; Horton 1967; 1993; Kapferer 2003; Tambiah 1984) and, more recently, witchcraft discourses in relation to social, material and cultural changes following 'modernization' and 'globalization' (Comaroff and Comaroff 1993; 1999; Geschiere 1997; Green and Mesaki 2005; Sanders 2003; 2006).

In the case of the Wayao street vendors, however, I am interested in the micropolitical significance of uchawi allegations as an attribution through which belonging and dependence were evaluated, but also constructed, within the group. I understand such accusations in the context of close social proximity (as found at the kijiweni) as a kind of 'social diagnostic' (Moore and Sanders 2006: 20) that commented on moral issues such as anxieties over 'illicit accumulation' (Comaroff and Comaroff 1999).

Accusations of $u c h a w i$ were embedded in a social discourse about the morality of kinship relations. As I explain below, the street vendors discursively constructed their social relationships as kin and fellow Wayao as an egalitarian sociality in which none of them was considered better equipped than anyone else to cope with the challenges of urban life and the economy of the streets. Vendors who displayed their individual success at the kijiweni were promptly accused of making use of the illicit means of uchawi to outdo their colleagues.

With this focus on the micro-politics of kinship relations, the case presented here complements other studies of socialities in the so-called informal economy in urban Africa and other parts of the world (Castells and Portes 1989; Cross and Morales 2007; Graaff and Ha 2015; Hansen et al. 2013; Hansen and Vaa 2004; Hart 1973; 1992; 2010; Lindell 2010; Staples 2007; Tripp 1997). These often review informal workers' social relations in utilitarian terms, using theoretical concepts such as social networks or social capital (for example, Lomnitz 1977; Lourenço-Lindell 2002; Meagher 2006). Such studies offer valuable insights into

I use the Swahili term uchawi when referring to my area of study and 'witchcraft' to refer to the literature covering similar phenomena in other parts of Africa. 
the embeddedness of informal workers within wider urban social fields, and into the many entanglements of the informal economy with the formal economy. My perspective on the sociality of the Wayao street vendors differs from this approach because I draw attention to the vendors' own complex interpretations of their social relatedness beyond their 'rational' utilization of relationships (cf. Burt 1992). Sociality among the street vendors, understood as a process rather than as a network or structure, was continuously reinterpreted according to their own imaginations, motivations and ambitions (cf. Long and Moore 2013). This imaginative dimension of social relations is captured in this article through the concept of socially constructed narratives (Mattingly 1998; Ochs and Capps 1996; 2001; Ricoeur 1991; Zigon 2012) with which the actors made sense of their individual experiences in the city. The street vendors' rural background, ethnicity and kinship relations featured prominently in the narratives they lived by, providing a plausible explanation for their current situation in the city that they gave to themselves (and to the ethnographer).

\section{Eating and sleeping for free: from the village to the kijiweni}

The village was always present in the Wayao social imagination at the kijiweni in central Dar es Salaam, and it shaped their social relations in crucial ways (cf. Englund 2002). According to statements they made in interviews, their rural upbringing had impressed upon them notions of 'who they were' that they were unable to shake off. They told me that life in the village was characterized by poverty and a lack of education, and their rural upbringing had not prepared them for the challenges of urban life at all. In particular, they found that needing to plan ahead and budget their income to be able to pay bills for rent, electricity or their children's school fees posed a severe problem for them. The temporal requirements of the urban capitalist economy was not something that their earlier life in the agricultural cycle of their rural homes had prepared them for (cf. Bourdieu 2000). The Wayao at the kijiweni considered themselves to be entirely alike in their inability to plan for the future. While they envied rural migrants from other ethnic backgrounds for the support they appeared to give one another, the sameness they attributed to their own relations made it impossible for them to cooperate substantially or to trust each other.

Like the shoe vendors I discuss in this article, many thousands of people migrate to Dar es Salaam each year. Since it was founded in the 1880 s, the initially small town of around 5,000 inhabitants has grown into a metropolis of over 4.5 million (Iliffe 1979: 384-5; National Bureau of Statistics Tanzania et al. 2013). The reason for this rapid growth has been - and still is - the constant influx of mostly young people who leave their rural homes to seek better opportunities in the city. Despite frequent government policies that aim to improve the situation of small-scale peasants in rural areas, from the villagization programmes under President Julius Nyerere's socialist government in the 1970s to the Kilimo Kwanza ('Agriculture First') programme introduced by President Jakaya Kikwete in 2009, living conditions in rural areas remain harsh to this day. For ambitious youngsters, leaving their village and looking for greener pastures in one of the regional towns or the metropolis of Dar es Salaam is a prevalent life plan (Liviga and Mekacha 1998). Since most rural migrants have little formal education and often no 
capital, self-organized work and petty trade have been - and remain - their only viable sources of income. Formal employment with a work contract, regular salary, social security and insurance is a rarity in Dar es Salaam. In 2002, the National Bureau of Statistics acknowledged that more than 60 per cent of urban populations in Tanzania gained part or all of their income through 'informal' economic activities (National Bureau of Statistics Tanzania 2002: 58), and, in 2008, the 'street vendor population' in Dar es Salaam was estimated at 700,000 people (cf. Lyons and Msoka 2010: 1082). This kind of self-organized economic activity comprises the most vibrant economic sphere in the city today, providing opportunities for hundreds of thousands - if not millions - of people to earn a meagre livelihood or supplement low wages.

Growing up in their village, the Wayao in Dar es Salaam told me, they had imagined that life in the metropolis would be full of opportunities. For them, it had been a 'standard plan' to leave home and move to the city. Once they had finished the obligatory seven years of primary school, often around the age of sixteen or seventeen, if they could find a way to scrape together the bus fare, Dar es Salaam was the place to go. After they arrived, however, they soon realized that life in the city not only offered opportunities but also posed great challenges. In the villages, people subsisted on the produce of their own labour in their fields, albeit at an insecure and very basic level. In the city, on the other hand, everything cost money. Rent, food, water and electricity, transportation and clothes all had to be paid for, and that required budgeting and a degree of planning. Moving to the city, therefore, also meant entering into a capitalist cash economy. As they had no capital of their own to start a business, newcomers initially lived off the generosity of a male relative who would let them stay at his home. The system of kula kulala bure, 'eating and sleeping for free', as they jokingly termed their first few months in their relative's house, was what had made their arrival in the city possible. A young man who dreamed of finding a better life in the city could only pursue this aim by relying on his kin to give him shelter and food in the new urban environment. After he had established himself in the city, his own home would become a focal point for his younger relatives who also aspired to a life in the city.

However, sooner or later, kula kulala bure would lead to tensions in the household, when the host thought that the young relative had been given enough time to settle in, but he was not yet contributing to the living expenses. Urged by their benefactor to find their own means of support, the easiest way they could start earning a living was by following their host into the same business that he worked in. So, for a young Mwyao from a particular village in the south who initially lived with an uncle, cousin or brother in Dar es Salaam, it seemed that the obvious next step was to help his relative selling used shoes on the streets. This pattern of rural-urban migration accounted for the relative ethnic homogeneity at the kijiweni and the multiplex social relations among the vendors as kin, fellow villagers, neighbours and colleagues.

\section{Sharing is daring: entrustments at the kijiweni}

The Wayao shoe vendors depended on small-scale cooperation with their colleagues at the kijiweni in many ways. They shared the tools and materials necessary to 
refurbish their merchandise, and they had established a system of commissionbased sales, called winga, which allowed a vendor to sell a colleague's shoes if he had run out of capital to buy his own merchandise. Both instances, however, were tightly circumscribed temporally and monitored closely within the confines of the kijiweni. Such practices of entrustment (Shipton 2007) were not based on trusting kinship relations but were facilitated by whether reciprocal expectations had been met or not, and they did not engender more far-reaching and reliable relations of trust. In this way, on the one hand, the spatial confines of the backyard facilitated cooperation, since they allowed for the control of reciprocal arrangements. But, on the other, the density of the kijiweni also meant that the close social relations between shoe vendors were more transparent, and that, paradoxically, made any substantial long-term cooperation impossible.

The group of forty-five male vendors ${ }^{3}$ with whom I conducted fieldwork specialized in trading second-hand women's shoes, which they bought at Karume Market, the largest outlet for second-hand clothes and shoes in the city. After they visited the market by themselves in the early morning to buy shoes, they met at their kijiweni to wash, repair and refurbish their merchandise before embarking on individual tours around the streets looking for customers for the rest of the day. As an anthropologist, it made sense for me to participate as closely as possible in the shoe vendors' daily routines. I accompanied them to Karume Market and asked them to show me how to choose the most saleable shoes from the large piles in the market. In the backyard I learned how to wash, repair and shine my shoes. And, while accompanying them individually on their tours through the streets, I learned how to approach and address different groups of customers and negotiate prices with them. This participant observation allowed me to gather information that would have been difficult to acquire otherwise. As well as giving me a better understanding of the physical dimension of street vending and the many forms of tacit knowledge involved in this line of business, sharing time, tools and shoes with the street vendors gave me plenty of opportunity to engage them in informal conversations, which proved valuable sources of information, particularly since they generally had little time to spend on more structured interviews (cf. Malefakis 2015).

During my fieldwork I would always meet between ten and twenty shoe vendors at the kijiweni at mid-morning, when they were washing their shoes in plastic basins, stuffing them with padded wads of plastic bags to push them back into shape, refurbishing them with shoe polish or making minor repairs with a razor blade, a piece of rubber sole and some superglue. Since only some of the vendors possessed the tools necessary to prepare their merchandise for sale, brushes, shoe polish, rubber soles, razor blades and superglue were shared among them. Sharing followed a principle of reciprocity, and the vendors closely observed who would or would not return the favour of lending his brush or shoe polish to another colleague who had helped him out before. In addition,

\footnotetext{
${ }^{3}$ There are many female street vendors in Dar es Salaam, who mostly specialize in preparing and selling foodstuffs. The sale of clothes and shoes on the streets, however, is dominated by male vendors. Due to my own gender, it was easier for me to make contact with male vendors. This article, therefore, focuses on a group of male vendors.
} 
the entrusted materials always had to be used within sight of the owner, allowing him to watch how his colleague handled his resources.

I stand in the backyard with Cholo and apply shoe polish to my shoes. Beka comes along and asks us if we have any black polish. Cholo tells him that we do, but that he cannot take it with him. He tells him to bring his shoes and use our polish on site. Beka takes it out of the wooden box on the floor between us, and the two argue a little bit. In the end, Beka goes to fetch his shoes. ${ }^{4}$

The reciprocal arrangements of entrustment were centred on several shared wooden boxes in which the vendors stored their tools and shoes overnight at the kijiweni. Each box was used by five or six vendors and there was an agreement that everyone who shared a box could use the tools inside. Outside such reciprocal coalitions, however, joint use was considered 'sponging' and was, therefore, carefully controlled.

Such practices of entrustment were not expressions of a general atmosphere of trust among the vendors. These arrangements were only possible because of a narrow spatial and temporal circumscription, since the objects borrowed had to be used on the spot and could not be taken out of their owner's sight. The entrustment of the tools necessary to refurbish shoes was therefore facilitated because of the transparency and possibility of mutual observation provided by the narrow backyard space.

Winga arrangements - the entrustment of shoes to be sold on commission were not immediately evident within the group at the kijiweni; initially, they involved only two colleagues who agreed on the arrangement. Breaches of winga arrangements, however, often led to vociferous arguments among the vendors involved; these amounted to public allegations about the culprit that gave him a reputation for untrustworthiness and unsuitability for future winga arrangements. Apart from such a mobilization of shame, the notion of kinship as an egalitarian bond made more effective sanctions impossible.

Winga arrangements allowed a shoe vendor to diversify his own stock of merchandise. If he noticed that one of his colleagues had a shoe that might particularly interest one of his regular customers, he could ask him for it and the two would agree a price that the owner of the shoe would receive if the vendor sold it. Winga was also a kind of emergency insurance that enabled any shoe vendor who had lost his capital due to bad luck in business, and thus was unable to acquire his own merchandise, to get back to work. The winga arrangement meant that any money the vendor could negotiate from a buyer on top of the price he had agreed with the person who had given him the shoes was his to keep. In this way, a vendor with no money was slowly able to build up his own capital by selling his colleague's shoes.

In wing a arrangements, the entrusted objects were taken out of their owners' sight to be sold on the streets. However, the rules pertaining to winga were commonly known and accepted among the vendors at the kijiweni. Although breaches in winga arrangements occurred from time to time, I never witnessed any effective penalty for this imposed by the group. As the Wayao were convinced that none of

${ }^{4}$ Field notes, 19 July 2012. 
them were in a position to do better than any of the others or take on the role of leader, no individual was endowed with the power to impose sanctions on members of the group, such as fining a colleague who had breached a generally acknowledged agreement or even banning him from the kijiweni.

Malik arrives at the backyard and takes a can of shoe polish from Hamis's plastic bag. All of a sudden, Hamis starts shouting at Malik, calling him mshamba (literally 'villager', used derogatively). The others join in the rant. Malik does not comment but insolently goes on polishing his shoes. After he leaves, I ask Hamis why they had called him mshamba. He explains that Malik has a habit of taking winga from people and keeping all the money for himself. Then he would move on to a different kijiweni to do the same thing there to some other guy. Hamis repeats that Malik really is a mshamba and not a 'smart guy'. He says: 'He owes money to a lot of people here, but we don't chase him away because he's our relative.' 5

This short vignette illustrates the contradictory effects of kinship on social relations among the shoe vendors - as a simultaneously integrative and disintegrative force. Although kinship was the primary relationship between them, it was not a source of mutual trust per se. The Wayao did not cooperate because they were relatives, but despite the fact that they were related through kinship ties. Their narrative self-representation, detailed below, entailed a notion of sameness that hindered social stratification that would allow them to safeguard their arrangements of entrustment and effectively sanction breaches of contractual agreements. However, in situations of conflict, like that described above, kinship was invoked as the reason why the culprit could not just be expelled from the group. The Wayao were stuck in their kinship relations at the kijiweni.

\section{Narrating kinship in the city}

The many small instances of cooperation and entrustment during their working day led to a considerable degree of mutual dependence among the shoe vendors, which they loathed. Instead of regarding their multiplex social relations as the basis of a durable cooperation from which they might all benefit, they experienced the relative homogeneity of their group as inhibiting their individual aspirations to success. This negative notion of kinship was thrown into relief against their perception of the city as a social environment that offered new opportunities to network and cooperate with people from different regional and ethnic backgrounds. These opportunities to mingle with different people were regarded by some as offering a more versatile understanding of urban life than they could achieve by adhering to the behaviour and attitudes they had brought with them from the village.

In a group interview with three of the shoe vendors - Juma, Ibra and Musa - the men talked about their self-perception and what it meant to be closely entangled with relatives with whom they shared a common past, place of origin and ethnic identity. The self-ascriptions they expressed contrasted with what they perceived to be characteristics of other groups of rural migrants in the city, such as Wachagga,

${ }^{5}$ Field notes, 11 December 2012. 
Wahaya, Wasambaa or Wanyekyusa. Juma made the differences he perceived explicit:

Our horizon of understanding is limited. That's how our parents were, and now that we've come to the city we still stick to each other. We're all from the same place, and we haven't mingled with other people who might understand life better and could give us some inspiration. You can't learn anything new there [at the kijiweni]; the ideas we exchange there are the same ideas we brought with us from home. For other people in the city it's different. If one of us would go and cooperate with Wachagga, or Wahaya or Wasambaa, I believe they would change rapidly. ${ }^{6}$

Juma expressed his frustration with the fact that, despite being in an environment that offered opportunities to 'mingle with people' who might 'give us some inspiration' and thus expand their horizons, the Wayao at the kijiweni clung to one another and missed out on chances to experiment with alternative perspectives on, and solutions to, their problems.

In the same interview, Ibra elaborated on his perception of the performance of other ethnic networks in the urban economy:

Look at other places, where there are shops run by Wanyekyusa, people from Mbeya. If you go into their shops, all the employees are Wanyekyusa, all you will hear is their local language. Or in a Mchagga's shop, they will all be Wachagga, people from the north. But us from the south, we are not like that.

In a somewhat desperate tone, Ibra expressed his envy of people from other ethnic backgrounds. Yet being 'from the south', as he and his colleagues at the kijiweni were, their intimate relations caused malevolence and mistrust among them rather than giving them access to employment. Envy and jealousy among the Wayao were rooted in their notion of being equally ill equipped to succeed in the city, since they all shared a rural upbringing that they felt had left a negative imprint on their mentality.

The Wayao shoe vendors depicted life in their home village as marked by poverty and grim prospects for the future. They said that the deprivations they had experienced there had given them a mindset that was unsuited to the challenges of urban life. They told me that, as Wayao villagers, they were members of one of the poorest and most underprivileged groups in the country, a group that lagged behind considerably in terms of maendeleo, development, a concept that played an important role in Tanzanian public and political discourse. Their families endured a life of hard manual labour in a subsistence economy. Above all, the Wayao at the kijiweni thought that the education provided by village schools was completely inadequate. All in all, they felt that village life did not prepare a young man to cope with the realities of life in a city. A particular problem many of my interlocutors mentioned was their inability and unwillingness to think ahead and plan for the future. As Juma explained:

${ }^{6}$ Interview, 21 September 2011. 
We are from the same village, and it's no secret that it's much better if you mix with people from different walks of life. Because everyone has their own ideas, so you can pick up the thoughts of different people. But all the ideas we exchange here [at the kijiweni] are the same as in the village. They're not appropriate to the city. In the village people sometimes don't even get hold of a thousand shillings ${ }^{7}$ in a whole month. Because food is free in the village, you cultivate the fields, then you eat. That's why we don't think much about how our lives will be later.

Juma associated their 'village thoughts' with a general lack of forward planning. In the villages, he recounted, they had - quite literally - lived from hand to mouth. In the city, however, their business required them to save part of their turnover in order to reinvest, and they had to save some of their net profits in order to be able to pay rent, electricity bills, their children's school fees, and so on. In other words, urban life required them to plan ahead and to budget the money they obtained. In this respect, Juma continued, all of his fellow Wayao were equally ill equipped for life in the city. For the Wayao at the kijiweni, therefore, their relatives in the city represented the life they had wanted to escape from in the first place. They felt stuck in a kind of gridlock, incapable of making it on their own, yet rejecting the idea of depending on one another.

Musa summarized the arguments all three made about the relationship between their sameness and a social climate of mutual disrespect and even contempt:

Because I know which house Ibra was born in, I cannot accept his advice. It's like: 'Who do you think you are?' Maybe this attitude will vanish with the younger generation. Our elders already had that mutual contempt for one another. Like, everybody should mind their own business, and nobody should think they are better than the rest.

In this statement, Musa's allusion to the house in which Ibra was born referred to the intimate knowledge they had about one other. Knowing each other so well including the fact that they had all had a poor education - led to a moral maxim of an egalitarian kind, turning past experience into a principle that guided future expectations. From their past socialization in the same unfavourable conditions, they concluded that none of them would be able to succeed in the future. Their unwillingness to accept the superiority of any of their fellow Wayao even spilled over into outright mutual contempt. My three interviewees emphasized that this was not something they had learned on arrival in the city; instead, they related such sentiments to their family background. Ibra stated this most clearly:

Since that contempt has been going on for a long time, it's become something like a heritage for us. It's like, for instance, if your father has a certain character trait, this trait will take hold of you too, and your kids will have this trait as well.

In a somewhat desperate tone, his cousin Juma added that they were well aware of the consequences of their negative stance towards one another for their daily interactions, but there was no way to let go of the habit: 'Ndivyo tulivyo!' - 'That's how we are!' he concluded.

\footnotetext{
${ }^{7}$ At the time of my research, 1,000 Tanzanian shillings were equivalent to around $€ 0.50$.
} 


\section{Uchawi as the flip side of social proximity}

The notion of all-encompassing sameness that the shoe vendors' narrative revolved around led to constant anxieties at the kijiweni if one of them displayed any signs of individual success. If any of the vendors appeared at the kijiweni with considerably more than the usual five or six pairs of shoes that the other vendors were able to afford, and subsequently occupied more space in the backyard to wash, dry and repair them, his colleagues immediately commented on his ostentatious display. Sometimes jokingly, but often with an accusatory tone, they told him that his achievement must have resulted from his use of a hirizi (charm) or some other dawa (medicine). The accused would defend himself and deny using any illicit means - or even reject the idea that anything like uchawi existed at all. There were, however, instances when there was supposedly some evidence of hirizi being used by vendors.

When I discussed the topic of uchawi with several shoe vendors, some of them recounted an incident when they had witnessed one of their group dropping a suspicious bundle from his pocket one day in the backyard. They had immediately spotted what they identified as a hirizi and accused the vendor in question of betraying his colleagues by being so ambitious that he had resorted to magic. The accused had quickly collected the item from the floor, put it back in his pocket and publicly claimed that he had been consulting a mganga, a traditional healer, to cure a stomach ache that he was suffering from. His explanation, however, did not convince the others, who cited this example more than once as evidence that uchawi was being used at the kijiweni.

For the Wayao vendors, uchawi was closely connected to notions of locality, kinship and belonging. In many conversations and interviews, my interlocutors pointed out that their colleagues and fellow Wayao consulted their local mganga during occasional visits to their rural homes. There, they allegedly obtained medicines for protection from uchawi along with hirizi, lucky charms to be used for specific purposes - in their case, mostly business success. In the villages, uchawi was closely related to social proximity and kinship. Similar to Peter Geschiere's accounts of the Maka in Cameroon (Geschiere 2003), the Wayao viewed close kinship relationships as a particularly potent source of uchawi powers. The Wayao's association of kinship not with solidarity, benign reciprocity or altruism but instead with the malevolent powers of witchcraft held true both in their home village and at their kijiweni in downtown Dar es Salaam. For the Wayao vendors, uchawi was the 'dark side of kinship' (ibid.). Because the social proximity of their relationships was often experienced as a factor that inhibited their personal success in life, the notion of uchawi was frequently invoked as a socially relevant explanation for an individual's bad luck. As the following story about Rahim shows, however, uchawi allegations were not employed to dissolve burdensome social relations, but as an expression of belonging that shaped, and even amplified, intimate social relations at the kijiweni.

\section{Pinned down by dirty magic: the story of Rahim}

Rahim was one of the oldest vendors at the kijiweni. Born in the southern village in 1969, he had moved to Dar es Salaam in 1995 and had been one of the first street 
vendors at the kijiweni. 'I am like a native of this place [the kijiweni]. We created this place for the others. If it weren't for us, I don't know where they would be now,' he stated, summarizing his rootedness at the kijiweni. He claimed that many of the currently active shoe vendors - notably his two younger brothers had been initiated into the business by him.

He had come to Dar es Salaam with aspirations similar to those of many other youths, to 'find a life' ('Kutafuta maisha'). He had initially enjoyed considerable economic success selling electrical equipment in the streets downtown, but the money he made had gone to support a drinking habit that he had formed soon after arriving in the city. 'I squandered my life in those years,' he said with regret. His wife had left him some years earlier, taking their child with her, and ever since then he had lived the life of a msela, a bachelor and loner. He had no capital of his own and depended completely on regular winga arrangements with two or three of his colleagues to earn a little money. Despite his relative seniority, his inability to support himself, coupled with his occasionally jittery behaviour when drunk, made Rahim a laughing stock at the kijiweni. Tall and skinny, with a cheap pair of sunglasses covering his red-rimmed eyes, he agreed to be interviewed one day. In a voice made hoarse by cigarettes and cheap spirits sold in little plastic bags, he described his intimate relationship with the others at the kijiweni:

I'm telling you, these kids, they know me inside out. That's how well they know me. Even if I dropped dead today from bad luck, they would take care of my corpse and take it home to my village. And they wouldn't have to ask the way! It's straight to my mother's house. You see? And if they had a problem, I would go straight to their mother's home. I know them, I know them completely. ${ }^{8}$

Rahim, I should add, had an ambivalent relationship with his home village. Since the day he left in 1995, he had never returned to visit his mother. He had chased the dream offered by the city, but, after almost twenty years in Dar es Salaam, had nothing to show for it.

If I go back, I would have to prepare myself a bit. I want to take care of my mother's living conditions. I would want her to move into another house. The house she's been living in up to now only has a thatched roof. That's what's strangling my soul, and that's why I stay here with these kids [at the kijiweni].

Rahim believed that there was no way he could return to his home village; that the maternal ties had been severed a long time ago. Considering his personal relationship to his village and his mother, along with a yearning for home and his sense of failure, what he said about his colleagues taking his dead body to his mother's house can be understood as an expression of longing for home and of belonging to the sociality of the kijiweni. 'These kids' were the only family he had left. He imagined them one day carrying his corpse along the road he felt too embarrassed to travel while alive. That was how well they knew him, and that was how much he depended on them.

\footnotetext{
${ }^{8}$ Interview, 4 February 2012.
} 
Yet, as comforting as the idea of being surrounded by people who would take care of him even after death might be, Rahim did not linger on the subject for long, continuing instead with a statement that showed the flip side of his intimate relationships at the kijiweni:

Those kids, when they came from the village, they were very humble. But now they know the streets, they know how to make money. Their respect has declined. Do you see how they humiliate a grown-up like me? They look at me as if I have no brains. They know I am their elder, but they abase me ... If God helps me find work, I will leave here and go to some other place.

His desire to leave the kijiweni notwithstanding, Rahim was completely economically dependent on his social relationships there. Yet he strongly resented the fact that he was so closely enmeshed in relationships of dependence with his relatives:

You know, when you're in the same place with three or four guys from the same kabila [Swahili: 'tribe'], respect will decline. Respect will decline, Alexi ... Even if I made a lot of money here, I would not stay. I would move away, to mingle with Wandengereko, with Wazaramo, or the like. I could even relax with Wasukuma. But these kids here, they use mambo ya kiswahili ['Swahili affairs', a colloquial metaphor for uchawi practices]. They're walking with uchawi mchafu - with dirty magic - it's very dangerous.

Similar to the comments cited in the group interview above, Rahim also considered that a more heterogeneous social network in terms of ethnic background would have positive effects on his situation, blaming the ethnic homogeneity at the kijiweni for the waning respect he had experienced. Without making a direct statement about the causal relationship between close social proximity and the proliferation of uchawi, Rahim proceeded from explaining his intimate relationships with his peers to a general statement about the negative attitudes among members of his ethnic group, and then jumped to a conclusion that related those negative attitudes to practices of uchawi. According to Rahim, using uchawi to prevent another person's financial progress was 'typical' of the way his relatives treated one another, in their home village as well as in the city. In their rural places of origin, he explained, uchawi was closely related to envy and disdain for fellow villagers' economic success:

This situation started with our elders ... Even if I made some money today and returned to my home village to start a business there - for instance, buying a grinding machine for corn - it wouldn't work. Even if it was a brand-new machine, I would have to go and see a mganga before I bought it. He would come and prepare the place. That's when the machine would work ... People, they kill you, they hate you just like that. They hate you, they hate you, they hate you. They don't want any progress.

The way in which Rahim depicted uchawi as occurring in situations where individual ambitions for advancement provoked envy among an individual's peers resonates with the literature on witchcraft as a moral discourse in which 'conspicuous successes' (Geschiere 1997: 69), according to local ideology, need to be levelled out. In the hypothetical situation in which Rahim managed to succeed in business, he would prefer to change his business location, mingling with people outside his 
group of relatives and fellow Wayao, so that he could escape the watchful eyes of his colleagues in the backyard. But, entangled as he was in intimate social relationships at the kijiweni, the state of Rahim's affairs was an open book to his peers. He felt entirely at their mercy. In the narrative he related to me about his life at the kijiweni, his colleagues would immediately see through all his attempts to achieve success, to break free from the confinement to which they had pinned him down, by means of uchawi.

It is important to note here that their 'dirty magic' was not a means of terminating social relationships. Instead, as Rahim interpreted it, it was a way to pin him down in his unfortunate situation. He expressed the effects of the uchawi his peers used on him with a metaphor of detainment: 'They locked me up here, those kids are keeping me down in this situation,' he said. That was the 'dark side' of social proximity as Rahim experienced it.

\section{On the flip side of uchawi: replicating kinship-like relations}

Although uchawi allegations were the dark side of the social intimacy Rahim experienced at the kijiweni, they also had the positive effect of an integrating force, by subjugating the accused to a moral narrative about kinship relations. Geschiere's main argument is that witchcraft in Africa has too often been mistaken for a counterpoint to kinship, whereas it is, in fact, the 'dark side of kinship' (Geschiere 2003) - in other words, an integral element of it. Yet, at the kijiweni, the uchawi discourse was not confined to kin or to members of a single ethnic group. As the previous discussion has shown, uchawi allegations occurred in social relationships that were particularly close and significant, therefore the most intimate ties (such as kinship relationships) were the most prone to such accusations. Inverting that argument, however, uchawi accusations outside intimate kinship relationships can be understood as exposing the perceived proximity and significance that actors attributed to their social relationship with the accused. Where the primary features of belonging - such as kinship, a shared ethnic identity or a shared local origin - were missing, the narrative of kinship relations nevertheless reached out to connect other individuals to the sociality by trying to include them in a discourse of morally appropriate conduct. This was the case when the social relationship with that individual was highly relevant for the group's sociality. Thus, uchawi accusations marked a zone of significant social relationships, by subjugating the accused to the 'code for conduct' (Schneider 1968: 29) associated with relatives. In such instances, the 'negative' perception that a social relationship was infested with uchawi was turned into a positive evaluation of the significance of a social relationship.

Patrick was an exceptional individual at the kijiweni in many respects. He was not a Mwyao from southern Tanzania, but was born in the Kilimanjaro region in northern Tanzania and identified himself as an Mpare. Accordingly, his migration to Dar es Salaam had followed a different route, both geographically and socially. He had not been introduced to the business of selling shoes by a relative from his home village, but by an acquaintance he had met in the city. This contact had initially taught him the business of selling shoes in the poorer residential areas known as uswahilini. After realizing the different commercial potentials of various areas 
in the city, Patrick and his colleague had moved their business from the poor outskirts into the more promising central business district in downtown Dar es Salaam, where both subsequently established themselves at the Wayao vendors' kijiweni and built relationships with them over time. The relationships that Patrick maintained with his colleagues were, therefore, not something they had nurtured from birth; instead, they had to be continuously created and maintained.

Patrick did not participate a priori in the social imagination and narrative of transparency and egalitarianism that the Wayao vendors associated with being kin. While the narrative of kinship that the Wayao lived by made trustful relations for them impossible, Patrick was a trusted and admired confidant for many of them. Some of the Wayao told me that they thought Patrick listened to them seriously and was ready to give advice and, sometimes, substantial help in situations where they did not dare turn to their relatives. They suspected that their relatives would use their confessions against them, turn down their requests for help, and gossip behind their backs about the personal misfortunes and problems they had.

Most importantly, Patrick was the only shoe vendor at the kijiweni who frequently generated considerable profits, which he reinvested in his stock. He sometimes owned twenty or more pairs of shoes, which made it impossible for him to sell all of them by himself in the streets; even the most experienced shoe vendors could manage to carry only ten or eleven pairs in their hands. Patrick therefore often had to distribute some of his many pairs of shoes to his colleagues via winga arrangements. For unlucky figures - particularly Rahim - he was a dependable source of credit in the form of merchandise. In fact, Patrick had established permanent lending relationships of commodity giver and taker with Rahim and two or three other vendors.

Patrick's success became obvious at the kijiweni when his shoes occupied most of the backyard areas that the vendors used to dry their shoes after washing them. They took up the entire surface of one or two large black plastic tanks and spread out over an adjoining staircase; they hung from lattice gates at the entrances of adjacent offices, provoking many colleagues passing in and out of the backyard in the morning to comment on his ostentatious display. They called him a mchawi (Swahili: practitioner of uchawi), both behind his back and directly to his face. When Patrick heard this, however, he rejected it and stressed that his success was nothing more than the result of his astuteness in reinvesting his profits in his business. He argued that more pairs of shoes would yield larger profits and thus enable the continuous growth of his business. He said that only the Wayao believed that uchawi could influence such a simple matter as trade. According to him, uchawi had come to the kijiweni with the Wayao and pertained only to them.

Accusing Patrick of using uchawi to increase his sales was not merely a moral commentary on his potentially antisocial aspirations for self-betterment. After all, his individual success was something many of the shoe vendors depended on. When they called him a mchawi, they were not so much reminding him of their aversion to individual ambition, but implicitly commenting on the value they placed on their relationships with him, as somebody who gave them moral support and credit in the form of merchandise. In this way, they reminded him to reinforce his relationships of solidarity with his colleagues by letting them share in his success. The uchawi discourse at the kijiweni thus also became a discourse of belonging, as it commented on the fact that the accused was worthy 
of scrutiny, indicating that relationships with him were particularly important to the others. Outperforming his peers amounted to distancing himself from them, with the consequence that the group might lose the benefits of being related to him. Calling him a mchawi discursively put pressure on him to distribute his surplus success to the group. Rather than expressing their wish to distance themselves from the illicit use of uchawi, such allegations, conversely, stressed the significance the others attributed to their relationship with Patrick.

\section{Conclusion}

For the Wayao at the kijiweni, their kinship relations were laden with culturally constructed notions of intimacy, dependence, contempt and mistrust. The complex meanings that being related entailed for them, analysed here as a narrative construction of kinship, show that kinship relations cannot be understood only as cultural constructs (Read 2007), but that the everyday experience of being related may be full of contradictions that need to be constantly navigated in specific situations.

Kinship relations had initially formed the nucleus of sociality among the Wayao shoe vendors. They had grown up together in the same village and helped one another to migrate to Dar es Salaam and gain a foothold in the business of street vending. Working and living in the city, however, they were forced to constantly reflect on the sociality they created and recreated every day in the swiftly changing urban environment. The heterogeneity of the city was perceived as having the potential to expand their horizons of understanding, and thus to improve their overall economic and social situation. The Wayao at the kijiweni observed how rural migrants from other parts of the country made better use of their ethnic networks and hence became wealthier in the urban economy. In contrast, they felt that they were restricting and constraining each other, always trying to prevent any one of them from getting ahead of the others in business.

The Wayao vendors associated their rural upbringing with poverty and a lack of education, and they considered their background insufficient to cope with urban life and the economy of the street. In that respect, they believed, they were all alike. The claustrophobic sentiments engendered by their intimate relationships were amplified by the narrow physical structure of the kijiweni, which fostered mutual observation and surveillance. While, on the one hand, this spatial proximity facilitated small-scale and short-term cooperation, such as the entrustment of tools, on the other hand it fostered an air of mistrust and social control. Constant exposure to their colleagues' gaze, coupled with the notion of all-encompassing mutual knowledge, ultimately led to the shoe vendors' inability to trust each other. The absolute sameness the Wayao claimed for themselves did not serve as a basis of 'robust information' for trust (Corsin Jiménez 2011: 180); on the contrary, their lack of trust stemmed precisely from that intimate knowledge about one another. The assumed transparency in their social relations left no room for any ambivalence that might be overlooked to give individuals the benefit of the doubt and, thus, generate trust (cf. Möllering 2001; 2006).

In the atmosphere of constant mistrust at the kijiweni, any deviance from the expected egalitarian sameness was frowned upon and often commented on via 
an idiom of uchawi. Uchawi among the Wayao street vendors should not be understood as a sign of a 'pre-logical mentality' (Lévy-Bruhl 1978) or a 'primitive' rationality that was fundamentally incompatible with Western thought, but rather as a 'normative ideational system' (Tambiah 1984: 92) that included 'moral rules' (Evans-Pritchard 1978: 98) about proper social conduct. As in E. E. Evans-Pritchard's description of the Azande's belief system of witchcraft, oracles and magic in his landmark study, accusing a fellow shoe vendor of uchawi meant charging him with 'anti-social sentiments' (ibid.) and actions that contradicted the group's shared value system. Such accusations occurred against a narrative of egalitarianism that rendered both social and economic life at the kijiweni a zero-sum equation (cf. Sanders 2006: 170) in which one individual's achievement was assumed to diminish the others' chances of success. Thus, when the shoe vendors suggested that a colleague's performance in the market had been enhanced by the illicit use of uchawi, they were commenting not only on his 'magically' mediated relation to the market, but also on his relationship to them. In this way, they accused him of claiming more for himself than was legitimate, of striving for pre-eminence when he was expected to stay in line with his colleagues.

However, as Evans-Pritchard has argued regarding the Azande, witchcraft used to express resentment presupposes concrete social relationships lived in close spatial proximity (Evans-Pritchard 1978: 95) that allow for continuous interactions in which all those involved can invoke shared notions of proper conduct or solidarity (Multhaupt 1990: 92). From this perspective, witchcraft allegations presuppose that the accused can legitimately be called to order, as the social relationships between the accusers and the accused involve shared values and moralities with which the accused is compelled to comply. Thus, since witchcraft accusations are grounded in a shared system of values and a shared morality, they can indeed be seen as 'indexes of social relations' (Marwick 1952: 120).

Understood in this way, the proliferation of uchawi accusations at the kijiweni may have quite a different significance for the sociality under study than merely hinting at anxieties and envy among the shoe vendors. As part of a shared narrative that was an inherent dimension of their sociality, uchawi allegations were attempts to enter into a conversation that evolved from an accusation of illicit individual aspirations into a broader discourse about belonging and the meanings of kinship relations. Uchawi accusations were not about the revocation of dysfunctional social relationships, but rather about their continuation as despised, yet indispensable, resources that the vendors needed to maintain in order to earn a living on the streets.

Kinship relations at the kijiweni were full of contradictions. While the shoe vendors were bound together through tight and multiplex social relations as kinsmen, Wayao, fellow villagers, colleagues and neighbours, their close social proximity frequently flipped into a disintegrative social force that blew them apart. However, the negative sentiments of mistrust, jealousy and disdain that found their most dramatic expression in uchawi accusations were not opposed to an otherwise harmonious notion of being related to one another. In fact, they sprang from the same sources as the binding forces of sociality. Thus, paradoxically, such allegations that, at first glance, appeared to be directed at the disassociation of social relations ultimately revealed an integrative social force. 


\section{References}

Bourdieu, P. (2000) Die zwei Gesichter der Arbeit. Interdependenzen von Zeit- und Wirtschaftsstrukturen am Beispiel einer Ethnologie der algerischen Übergangsgesellschaft. Konstanz: UVK Universitäts-Verlag Konstanz.

Burt, R. S. (1992) Structural Holes: the social structure of competition. Cambridge MA and London: Harvard University Press.

Castells, M. and A. Portes (1989) 'World underneath: the origins, dynamics, and effects of the informal economy' in A. Portes, M. Castells and L. A. Benton (eds), The Informal Economy: studies in advanced and less developed countries. Baltimore MD and London: Johns Hopkins University Press.

Comaroff, J. and J. L. Comaroff (eds) (1993) Modernity and its Malcontents: ritual power in postcolonial Africa. Chicago IL and London: University of Chicago Press.

Comaroff, J. and J. L. Comaroff (1999) 'Occult economies and the violence of abstraction: notes from the South African postcolony', American Ethnologist 26 (2): 279-303.

Corsin Jiménez, A. (2011) 'Trust in anthropology', Anthropological Theory 11: 177-96.

Cross, J. and A. Morales (eds) (2007) Street Entrepreneurs: people, place and politics in local and global perspective. London and New York NY: Routledge.

Englund, H. (2002) 'The village in the city, the city in the village: migrants in Lilongwe', Journal of Southern African Studies 28 (1): 137-54.

Evans-Pritchard, E. E. (1965) Theories of Primitive Religion. Oxford: Clarendon Press.

Evans-Pritchard, E. E. (1978) Hexerei, Orakel und Magie bei den Zande. Frankfurt: Suhrkamp.

Geschiere, P. (1997) The Modernity of Witchcraft: politics and the occult in postcolonial Africa. Charlottesville VA and London: University of Virginia Press.

Geschiere, P. (2003) 'Witchcraft as the dark side of kinship: dilemmas of social security in new contexts', Etnofoor 16 (1): 43-61.

Graaff, K. and N. Ha (eds) (2015) Street Vending in the Neoliberal City: a global perspective on the practices and politics of a marginalized economy. New York NY and Oxford: Berghahn Books.

Green, M. and S. Mesaki (2005) 'The birth of the "salon": poverty, "modernization", and dealing with witchcraft in southern Tanzania', American Ethnologist 32 (3): 371-88.

Hansen, K. T. and M. Vaa (eds) (2004) Reconsidering Informality: perspectives from urban Africa. Uppsala: Nordiska Afrikainstitutet.

Hansen, K. T., W. E. Little and B. Lynne Milgram (eds) (2013) Street Economies in the Urban Global South. Santa Fe NM: School for Advanced Research Press.

Hart, K. (1973) 'Informal income opportunities and urban employment in Ghana', Journal of Modern African Studies 11 (1): 61-89.

Hart, K. (1992) 'Market and state after the Cold War: the informal economy reconsidered' in R. Dilley (ed.), Contesting Markets: analyses of ideology, discourse and practice. Edinburgh: Edinburgh University Press.

Hart, K. (2010) 'Africa's urban revolution and the informal economy' in V. Padayachee (ed.), The Political Economy of Africa. London and New York NY: Routledge. 
Heinz, A. (1997) 'Savage thought and thoughtful savages: on the context of the evaluation of logical thought by Lévy-Bruhl and Evans-Pritchard', Anthropos 92: $165-73$.

Horton, R. (1967) 'African traditional thought and Western science', Africa 37 (1): $50-71$.

Horton, R. (1993) Patterns of Thought in Africa and the West. Cambridge: Cambridge University Press.

Iliffe, J. (1979) A Modern History of Tanganyika. London, New York NY and Melbourne: Cambridge University Press.

Kapferer, B. (2003) Beyond Rationalism: rethinking magic, witchcraft and sorcery. New York NY and Oxford: Berghahn Books.

Lévy-Bruhl, L. (1978) 'Das Gesetz der Teilhabe' in L. Petzold (ed.), Magie und Religion. Beiträge zu einer Theorie der Magie. Darmstadt: Wissenschaftliche Buchgesellschaft.

Lindell, I. (ed.) (2010) Africa's Informal Workers: collective agency, alliances and transnational organizing in urban Africa. Uppsala, London and New York NY: Nordic Africa Institute and Zed Books.

Liviga, A. J. and R. D. K. Mekacha (1998) Youth Migration and Poverty Alleviation: a case study of petty traders (Wamachinga) in Dar es Salaam. Dar es Salaam: REPOA.

Lomnitz, L. A. (1977) Networks and Marginality: life in a Mexican shantytown. New York NY: Academic Press.

Long, N. J. and H. L. Moore (eds) (2013) Sociality: new directions. New York NY and Oxford: Berghahn Books.

Lourenço-Lindell, I. (2002) Walking the Tight Rope: informal livelihoods and social networks in a West African city. Stockholm: Department of Human Geography, Stockholm University.

Lyons, M. and C. T. Msoka (2010) 'The World Bank and the street: (how) do “doing business" reforms affect Tanzania's micro-traders?', Urban Studies 47 (5): 1079-97.

Malefakis, A. (2015) 'Rewarding frictions: fieldwork and street vending in Dar es Salaam, Tanzania', Zeitschrift für Ethnologie 140: 177-89.

Marwick, M. G. (1952) 'The social context of Cewa witch beliefs', Africa 22 (2-3): 120-35, 215-33.

Mattingly, C. (1998) 'In search of the good: narrative reasoning in clinical practice', Medical Anthropology Quarterly 12 (3): 273-97.

Mayer, P. (1963) Townsmen or Tribesmen: conservativism and the process of urbanization in a South African city. Cape Town: Oxford University Press.

Meagher, K. (2006) 'Social capital, social liabilities, and political capital: social networks and informal manufacturing in Nigeria', African Affairs 105 (421): 553-82.

Möllering, G. (2001) 'The nature of trust: from Georg Simmel to a theory of expectation, interpretation and suspension', Sociology 35: 403-20.

Möllering, G. (2006) Trust: reason, routine, reflexivity. Oxford and Amsterdam: Elsevier.

Moore, H. L. and T. Sanders (2006) 'Magical interpretations and material realities: an introduction' in H. L. Moore and T. Sanders (eds), Magical Interpretations and Material Realities: modernity, witchcraft and the occult in postcolonial Africa. London and New York NY: Routledge. 
Multhaupt, T. (1990) Hexerei und Antihexerei in Afrika. Munich: Trickster.

National Bureau of Statistics Tanzania (2002) 'Integrated labour force survey 2000/2001'. Dar es Salaam: National Bureau of Statistics Tanzania.

National Bureau of Statistics Tanzania, Office of Chief Government Statistician President's Office, and Finance, Economy and Development Planning Zanzibar (2013) '2012 population and housing census. Population distribution by administrative areas'. Dar es Salaam: Ministry of Finance.

Ochs, E. and L. Capps (1996) 'Narrating the self', Annual Review of Anthropology 25: 19-43.

Ochs, E. and L. Capps (2001) Living Narrative: creating lives in everyday storytelling. Cambridge MA and London: Harvard University Press.

Read, D. W. (2007) 'Kinship theory: a paradigm shift', Ethnology 46 (4): 329-64.

Ricoeur, P. (1991) 'Life in quest of narrative' in D. Wood (ed.), On Paul Ricoeur: narrative and interpretation. London: Routledge.

Sanders, T. (2003) 'Reconsidering witchcraft: postcolonial Africa and analytic (un)certainties', American Anthropologist 105 (2): 338-52.

Sanders, T. (2006) 'Save our skins: structural adjustment, morality and the occult in Tanzania' in H. L. Moore and T. Sanders (eds), Magical Interpretations and Material Realities: modernity, witchcraft and the occult in postcolonial Africa. London and New York NY: Routledge.

Schneider, D. M. (1968) American Kinship: a cultural account. Chicago IL and London: University of Chicago Press.

Shipton, P. (2007) The Nature of Entrustment: intimacy, exchange, and the sacred in Africa. New Haven CT and London: Yale University Press.

Simone, A. (2004) 'People as infrastructure: intersecting fragments in Johannesburg', Public Culture 16 (3): 407-29.

Staples, J. (ed.) (2007) Livelihoods at the Margins: surviving in the city. Walnut Creek CA: Left Coast Press.

Tambiah, S. J. (1984) Magic, Science, Religion and the Scope of Rationality. Cambridge: Cambridge University Press.

Tripp, A. M. (1997) Changing the Rules: the politics of liberalization and the urban informal economy in Tanzania. Berkeley CA and London: University of California Press.

Zigon, J. (2012) 'Narratives' in D. Fassin (ed.), A Companion to Moral Anthropology. Malden MA and Oxford: Wiley-Blackwell.

\begin{abstract}
For a group of Wayao street vendors in Dar es Salaam, Tanzania, kinship relations were simultaneously an advantage and a hindrance. Their migration to the city and entry into the urban economy had occurred along ethnic and kinship lines. But, as they perceived the socially heterogeneous environment of the city that potentially offered them opportunities to cooperate with people from different social or ethnic backgrounds, they experienced their continuing dependency on their relatives as a form of confinement. Against the backdrop of the city, the Wayao perceived their social relations as being burdened with an inescapable sameness that made it impossible to trust one another. Mistrust, contempt and mutual suspicion were the flip side of close social relations and culminated in
\end{abstract}


accusations of uchawi (Swahili: witchcraft). However, these accusations did not have a disintegrative effect; paradoxically, their impact on social relations among the vendors was integrative. On the one hand, uchawi allegations expressed the claustrophobic feeling of stifling relations; on the other, they compelled the accused to adhere to a shared morality of egalitarian relations and exposed the feeling that the accused individual was worthy of scrutiny, indicating that relationships with him were of particular importance to others.

\section{Résumé}

Les relations de parenté sont à la fois un avantage et une entrave pour un groupe de vendeurs ambulants wayao de Dar es Salaam (Tanzanie). Leur migration vers la ville et leur entrée dans l'économie urbaine se sont faites sur des lignes d'appartenance ethnique et de parenté. Mais alors qu'ils perçoivent l'environnement socialement hétérogène de la ville qui leur offre potentiellement des opportunités de coopérer avec des personnes de milieux sociaux ou ethniques différents, ils ressentent leur dépendance continue vis-à-vis de leurs parents comme une forme de confinement. Dans le contexte de la ville, les Wayao perçoivent leurs relations sociales comme étant chargées d'une similitude implacable qui empêche de se faire mutuellement confiance. La méfiance, le mépris et la suspicion mutuelle sont l'envers des rapports sociaux étroits et aboutissent à des accusations de uchawi (du swahili, signifiant sorcellerie). Néanmoins, ces accusations n'ont pas un effet désintégrant ; paradoxalement, leur impact sur les rapports sociaux entre vendeurs est intégrant. D'un côté, les accusations de uchawi expriment le sentiment claustrophobe des relations étouffantes ; de l'autre, elles forcent l'accusé à adhérer à une moralité partagée de rapports égalitaires et révèle le sentiment que l'accusé mérite qu'on le scrute, indiquant que les autres attachent une importance particulière aux rapports avec cet individu. 